\title{
ANTIBODY PRODUCTION AFTER INTRATRACHEAL INJECTION OF ANTIGEN
}

\author{
RIGNEY D'A UN OY
}

From the Department of Pathology, Tulane Unizersity, and The Rathbone Memorial Labora. tories of the Charity Hospital, New Orleans, Louisiana

The importance of the intratracheal route of inoculation as a possible practical measure for the production of antibodies was first suggested by Besredka. ${ }^{1}$ During his studies on anaphylaxis he observed that rabbits and guinea-pigs withstood large intratracheal injections of serum, and that the intratracheal inoculations of $B$. tuberculosis occasioned the production of specific antibodies for this organism. Recently Pfenninger ${ }^{2}$ has recorded the production of agglutinins for B. paratyphosus, of lysins for sheep erythrocytes, and of lysins for Vibrio cholerae after intratracheal injections.

It is not surprising that the intratracheal route for introducing an antigen should be followed by ready antibody response when we consider the high vascularity of the mucous membrane of the whole of the respiratory tract, and especially that of the trachea. Due to the numerous infoldings of various parts of this mucosa, considerable surface for absorption exists Goodwin, Segalos and Mayer $^{3}$ have observed practically instantaneous absorption of water injected intratracheally in dogs and rabbits Golin introduced eighteen liters of water within three hours in the trachea of horses without ill results. He also showed that salts of strychnine can be demonstrafed in the jugular vein four minutes after their intratracheal injection. Guieysse-Pellissier ${ }^{5}$ has shown that olive oil is readily absorbed hy the respiratory mucosa

During the course of this investigation an attempt was made to record the comparative antibody production achieved in gtuinea-pigs and rabbits by the injection of various antigens by diverse routes. Thus, agglutinin production after intraperitoneal, intravenous, and intratracheal injections of B. typhosus and B. dysenteriae (Flexner) was studied; production of precipitins for horse and human serums, of lysins for sheep and human red blood cells, and of bacteriolysins and bactericidins for Vibrion cholerae were similarly investigated.

Received for publication Oct. 24, 1921.

1 Ann. de l'Inst. Pasteur, 1919, 33, p. 882; 1920, 34, p. 361.

2 Ibid., 1921, 35, p. 237.

s Halliburton, Handbook of Phys., 1905.

1 Traite de Phys. Comp., 1888.

s Congress de Phys., 1920. 


\section{METHODS}

The animals used throughout the experiments were full grown healthy rabbits and guinea-pigs that had been isolated in thoroughly cleansed pens for three weeks before being used.

All bacterial antigens were prepared by suspending 48-hour agar growths of the various organisms in normal salt solution. No attempts at standardization of these suspensions were made, inoculations being accomplished with such unkilled suspensions and with organisms killed by $60 \mathrm{C}$. as indicated in the protocols.

Horse and human serums were obtained by venipuncture and diluted with equal parts of normal salt solution before inoculation; no preservatives were added, the various portions of such serum being aseptically handled and stored at $40 \mathrm{C}$.

Sheep cells and human cells were secured in the usual manner and washed 6 times with normal salt solution, $10 \%$ suspensions being used for inoculation.

Agglutination tests were made macroscopically with living organisms, the usual precautions as to control for each dilution in the presence of homologous serum being always observed. Final readings were made after 2 hours at $45 \mathrm{C}$ and overnight in the icebox. Precipitins were demonstrated by overlaying $0.2 \mathrm{cc}$ portions of various dilutions of the serum to be tested with the antigen in question. Readings were made after 45 mitutes at room temperature $(25-35 \mathrm{C}$.). The hemolytic titer of serums was determined by allowing decreasing dilutions of serum to be tested to act on $0.5 \mathrm{cc}$ portions of alexin (guinea-pig serum 1:10) and 5\% washed homologous erythrocytes. Final readings were made after 2 hours at $45 \mathrm{C}$. and after over night in the icebox. Bacteriolysins were studied by causing various dilutions of serum to be in contact with salt suspensions of viable organisms in the peritoneal cavity of normal guinea-pigs. Stained and unstained preparations of material secured by peritoneal puncture of such animals at varying intervals were observed, the technic being essentially that of Pfeiffer. Agar poured plates were also prepared with immune serum; in this manner relative determination of bactericidal power of serums was possible.

Intravenous and intraperitoneal inoculations were made in the usual manner. Intratracheal inoculations were made under ether anesthesia; the skin of the neck was incised in the midline and the trachea exposed. After steadying the trachea, the inoculating needle (usually a 24 gage) 

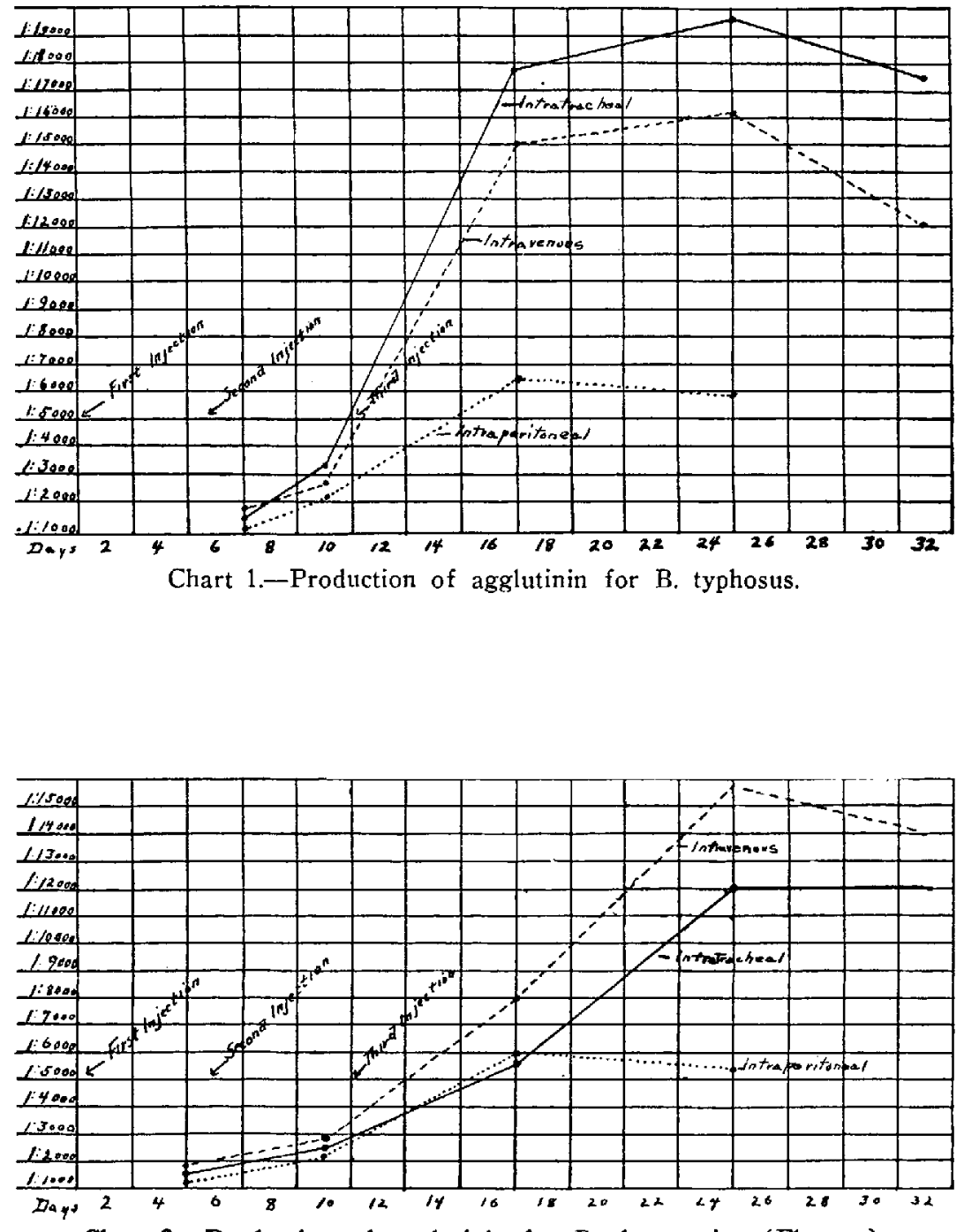

Chart.2.-Production of agglutinin for B. dysenteriae (Flexner). 
was thrust into the organ between the cartilaginous rings, and the inoculating material introduced slowly. By this method $15 \mathrm{cc}$ of fluid were readily injected into the trachea of full grown rabbits, with no inconvenience to the animal. The wounds were iodinized and the lips held together by a single catgut suture.

\section{EXPERI MENTAL}

Agglutinins.-For the production of these antibodies two bacterial species were employed, namely, B. typhosus and B. dysenteriae (Flexner). With each antigen 9 rabbits were injected, 3 intraperitoneally, 3 intratracheally and 3 intravenously, with intervals of 5 days between the inoculations. The first inoculation consisted of one half agar slant killed organisms, the second and third inoculations of one agar slant live organisms. Four days after the first, 4 days after the second, 6,14 and 21 days after the last, inoculations the agglutinating power of the various serums was determined. Charts 1 and 2 illustrate the results obtained.

Precipitins.-Human and horse serums were employed as antigens, 9 rabbits being used for each type of serum. Three intraperitoneal, intravenous and jntratracteal siroctations of $4 \mathrm{cc}$ of serum diluted with equal parts of inomal salt solut ingere made at intervals of 6 days.. Precipitin content of the immune serum was determined 5 days after:the first and second injections and 5, 10, and 20 days after the -isst injection (dharts 3 and 4 ):

Hemolysins $\because$ again 3 series or intraperitoneal, intravenous, and uatratracheal injections of sheep and

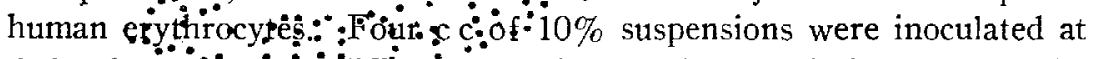
6 day intervals on 3 different occasions. The hemolytic power of the serum was determined 5 days after the first inoculation, 5 days after the second inoculation and 5,10,20 and 40 days after the last inoculation (charts 5 and 6).

Bacteriolysins and Bactericidins.-Six guinea-pigs were used in these experiments. Three were injected intraperitoneally and 3 intratracheally on 3 occasions, allowing 6 days to elapse between the injections. Killed and living cultures of Vibrio cholerae were used. Six days after the last inoculation the animals were bled and increasing quantities of their serum mixed with fixed quantities of actively growing agar cultures of Vibrio cholerae suspended in salt solution. Intraperitoneal injections of such mixtures were then made in normal 
guinea-pigs, and at suitable intervals portions of the peritoneal exudates were secured for study along the lines indicated by Pfeiffer. In addition, plating of mixtures of actively growing cultures and immune serums were made (table 1 ).

TABLE 1

Bacteriolytic and Bactericidal Powers of Produced Serums

\begin{tabular}{|c|c|c|c|c|c|c|}
\hline \multirow{2}{*}{$\begin{array}{c}\text { Guinea- } \\
\text { Pigs }\end{array}$} & \multirow{2}{*}{$\begin{array}{l}\text { Method } \\
\text { of } \\
\text { Inoculs- } \\
\text { tion }\end{array}$} & \multicolumn{2}{|c|}{$\begin{array}{c}\text { Hanging Drop Preparation } \\
\text { of Peritoneal Fluid } \\
\text { After Intraperitoneh } \\
\text { Inoculation of } 2 \mathrm{C} \text { c } \\
\text { Actively Growing } \\
\text { Bouillon Culture } \\
\text { V. Cholera }\end{array}$} & \multicolumn{2}{|c|}{$\begin{array}{c}\text { Stained Preparation } \\
\text { of Peritoneal Fluid } \\
\text { After Intraperitoneal } \\
\text { Inoculation of } 2 \mathrm{Oc} \\
\text { Actively Growing } \\
\text { Bouillon Culture } \\
\text { V. Cholera }\end{array}$} & \multirow{2}{*}{$\begin{array}{c}\text { Colonies } \\
\text { per C c } \\
\text { 24-Hour } \\
\text { Agar } \\
\text { Plates } \\
\text { (1 Ce Se- } \\
\text { rum + } \\
\text { C e } 24 \text { Hr } \\
\text { Boujllon } \\
\text { Culture } \\
\text { Plated } \\
\text { After } \\
4 \text { Hours } \\
\text { Incuba- } \\
\text { tion) }\end{array}$} \\
\hline & & $\begin{array}{c}\text { Fluid } \\
\text { Removed } \\
\text { 30 Minutes } \\
\text { After } \\
\text { Inoculation }\end{array}$ & $\begin{array}{c}\text { Fluid } \\
\text { Removed } \\
60 \text { Minutes } \\
\text { After } \\
\text { Inoculation }\end{array}$ & $\begin{array}{c}\text { Fluid } \\
\text { Removed } \\
\text { 30 Minutes } \\
\text { After } \\
\text { Inoculation }\end{array}$ & $\begin{array}{c}\text { Fluid } \\
\text { Removed } \\
60 \text { Minutes } \\
\text { After } \\
\text { Inoculation }\end{array}$ & \\
\hline 1 & $\begin{array}{l}\text { Intra- } \\
\text { peritoneal }\end{array}$ & $\begin{array}{l}\text { Few motile } \\
\text { forms; few } \\
\text { granular } \\
\text { organisms }\end{array}$ & $\begin{array}{c}\text { No motile } \\
\text { forms; granu- } \\
\text { lar, disintegrat- } \\
\text { ing organisms } \\
\text { only }\end{array}$ & $\begin{array}{c}\text { Many bizarre } \\
\text { shaped gran- } \\
\text { lar organisms; } \\
\text { few comma } \\
\text { shaped forms }\end{array}$ & $\begin{array}{l}\text { Mang granu- } \\
\text { lar organisms }\end{array}$ & 110,000 \\
\hline 2 & $\begin{array}{c}\text { Intra- } \\
\text { peritoneal }\end{array}$ & $\begin{array}{l}\text { Few motile } \\
\text { torms; few } \\
\text { grunular } \\
\text { organisms }\end{array}$ & $\begin{array}{c}\text { Markedly } \\
\text { granular } \\
\text { forms } \\
\text { only }\end{array}$ & $\begin{array}{c}\text { Many bizarre } \\
\text { shaped gran- } \\
\text { lar organfsms } \\
\text { few comma } \\
\text { shaped forms }\end{array}$ & $\begin{array}{l}\text { Few granu } \\
\text { ular rod } \\
\text { shaped } \\
\text { organisms }\end{array}$ & 225,000 \\
\hline 3 & $\begin{array}{l}\text { Intra- } \\
\text { peritoneal }\end{array}$ & $\begin{array}{l}\text { No motile } \\
\text { forms; granu- } \\
\text { lar organ- } \\
\text { isms only }\end{array}$ & $\begin{array}{l}\text { No organisms } \\
\text { recognizable }\end{array}$ & $\begin{array}{l}\text { Many granu- } \\
\text { lar torms; } \\
\text { oeeasional } \\
\text { normal appear- } \\
\text { ing organisms }\end{array}$ & $\begin{array}{l}\text { No organisms } \\
\text { recognizable }\end{array}$ & 360,000 \\
\hline 4 & $\begin{array}{c}\text { Intra- } \\
\text { peritoneal }\end{array}$ & $\begin{array}{l}\text { Many motile } \\
\text { organisms: } \\
\text { few granu- } \\
\text { lar forms }\end{array}$ & $\begin{array}{l}\text { Oceasional } \\
\text { motlle organ- } \\
\text { isms; most } \\
\text { forms gran- } \\
\text { litar }\end{array}$ & $\begin{array}{l}\text { Many normal } \\
\text { appearing or- } \\
\text { ganisms: few } \\
\text { granular } \\
\text { forms }\end{array}$ & $\begin{array}{l}\text { Few comma } \\
\text { shaped forms; } \\
\text { many attenu- } \\
\text { ated granular } \\
\text { organisms }\end{array}$ & 98,000 \\
\hline 5 & $\begin{array}{l}\text { Intra- } \\
\text { tracheal }\end{array}$ & $\begin{array}{c}\text { Many granu- } \\
\text { lar forms } \\
\text { only }\end{array}$ & $\begin{array}{l}\text { No organisms } \\
\text { recognizable }\end{array}$ & $\begin{array}{l}\text { Granular rod } \\
\text { shaped or- } \\
\text { ganisms only }\end{array}$ & $\begin{array}{l}\text { No organisms } \\
\text { recognlzable }\end{array}$ & 100,000 \\
\hline 6 & $\begin{array}{l}\text { Intra- } \\
\text { tracheal }\end{array}$ & $\begin{array}{c}\text { Many granu- } \\
\text { lar forms } \\
\text { only }\end{array}$ & $\begin{array}{l}\text { No organisms } \\
\text { recognizable }\end{array}$ & $\begin{array}{c}\text { Granular rod } \\
\text { shaped or- } \\
\text { ganisms only }\end{array}$ & $\begin{array}{l}\text { No organisms } \\
\text { recognizable }\end{array}$ & 1,000 \\
\hline 7 & $\begin{array}{l}\text { Intra- } \\
\text { tracheal }\end{array}$ & $\begin{array}{l}\text { Organisms } \\
\text { completely } \\
\text { disintegrated }\end{array}$ & $\begin{array}{l}\text { No organisms } \\
\text { recognizable }\end{array}$ & $\begin{array}{c}\text { Few granular } \\
\text { attenuated } \\
\text { rod shaped } \\
\text { organisms }\end{array}$ & $\begin{array}{l}\text { No organisms } \\
\text { recognizable }\end{array}$ & 55,000 \\
\hline 8 & $\begin{array}{l}\text { Intra- } \\
\text { tracheal }\end{array}$ & $\begin{array}{c}\text { Organjsms } \\
\text { completely } \\
\text { disintegrated }\end{array}$ & $\begin{array}{l}\text { No organisms } \\
\text { recognizable }\end{array}$ & $\begin{array}{c}\text { Few granular } \\
\text { attenuated } \\
\text { rod shaped } \\
\text { organisms }\end{array}$ & $\begin{array}{l}\text { No organisms } \\
\text { recognizable }\end{array}$ & 162,000 \\
\hline 9 & Control & $\begin{array}{l}\text { Actively } \\
\text { motile. coin- } \\
\text { ma shaped } \\
\text { organisms }\end{array}$ & $\begin{array}{l}\text { Actively } \\
\text { motile, com- } \\
\text { ma shaped } \\
\text { organisms }\end{array}$ & $\begin{array}{c}\text { Organisms } \\
\text { present: no } \\
\text { morphologic } \\
\text { changes }\end{array}$ & $\begin{array}{c}\text { Organisms } \\
\text { present: no } \\
\text { morphologic } \\
\text { changes }\end{array}$ & $\begin{array}{l}\text { Innum- } \\
\text { erable }\end{array}$ \\
\hline
\end{tabular}




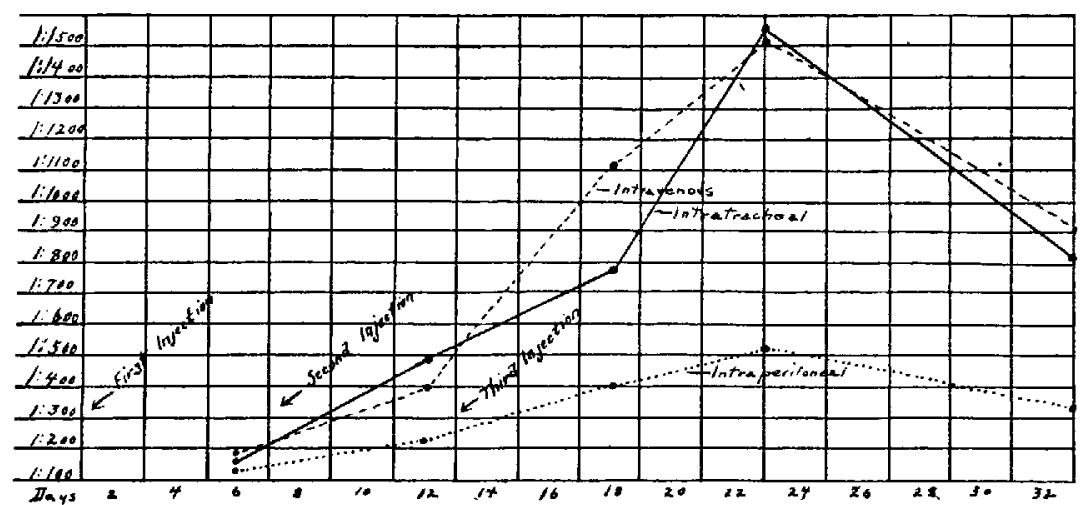

Chart 3.-Production of precipitin for human serum.

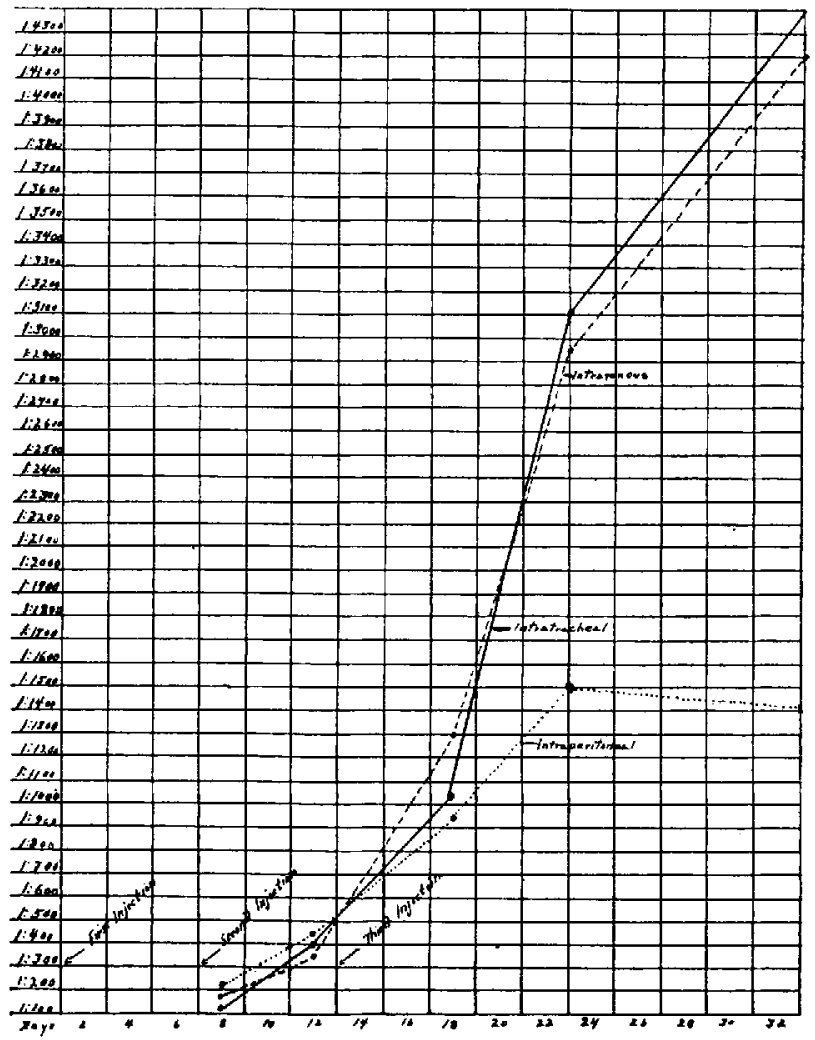

Chart 4.-Production of precipitin for horse serum. 
DISCUSSION

The data secured shows that the agglutinins produced by the intratracheal innoculation of $B$. typhosus appear in as large quantities and as early as when the intravenous route for injection is chosen. Considerably more of these immune bodies can be demonstrated after intratracheal inoculations than after intraperitoneal injections of similar amounts of antigen. Of the 3 animals inoculated intraperitoneally, the average agglutinin titer, 14 and 21 days after the last injection of antigen, was $1: 5,200$ and $1: 3,500$ with averages of $1: 15,000$ and $1: 11,000$ for the one surviving animal after intravenous injection and averages of 18,600 and 16,600 for the 3 animals injected intratracheally. Although 2 animals injected intravenously succumbed with no discernible lesions at necropsy, as happens so frequently with rabbits used for production of antiserum, no deaths occurred in the series inoculated intratracheally. With B. dysenteriae (Flexner) as antigen the results obtained were practically similar to those for B. typhosus. Here the average agglutinating titer, 14 and 21 days after intraperitoneal injections was 4,500 and 4,800 for 3 animals in comparison with 14,500 and 13,000 for 2 animals after intravenous injections and 11,000 and 11,000 for 3 animals following intratracheal inoculations. It would then appear to be fairly well established that for certain organisms, agglutinins can be produced by intratracheal inoculations with results, judged by titer of serums and time of appearance of immune bodies, as good and probably with more safety than by intravenous injections.

With precipitin production the results secured after intratracheal injection were generally as good as those following intravenous inoculations. Here the titer of intravenously produced antihuman serums averaged 1,500 and 800,10 and 20 days after final injections as compared to averages of $1: 1,500$ and $1: 700$ for intratracheally produced serums. After injections of horse serum the comparative titers were $1: 2,800$ and $1: 4,100$ for intravenous serums and $1: 3,000$ and $1: 4,300$ for intratracheal serums, 10 and 20 days, respectively, after injections of similar doses of antigen. With both of these antigens intraperitoneal injections consistently resulted in serum of very low precipitin titer.

For hemolysins produced by human and sheep erythrocytes, the results were slightly different. Consistently these antibodies would appear in lesser amounts and later in the animals injected intratracheally than in those injected intravenously. The ultimate titers, however, of the serums were practically identical. Thus the average titer for 3 animals injected intratracheally with human cells 5, 10, 20 


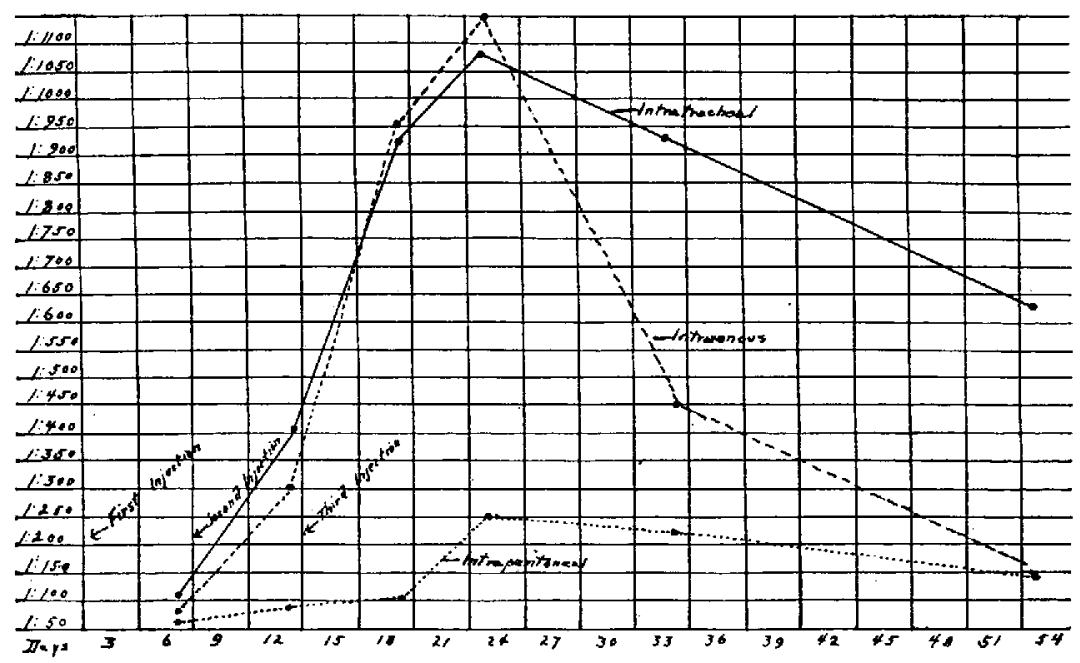

Chart 5.-Production of hemolysin for human erythrocytes.

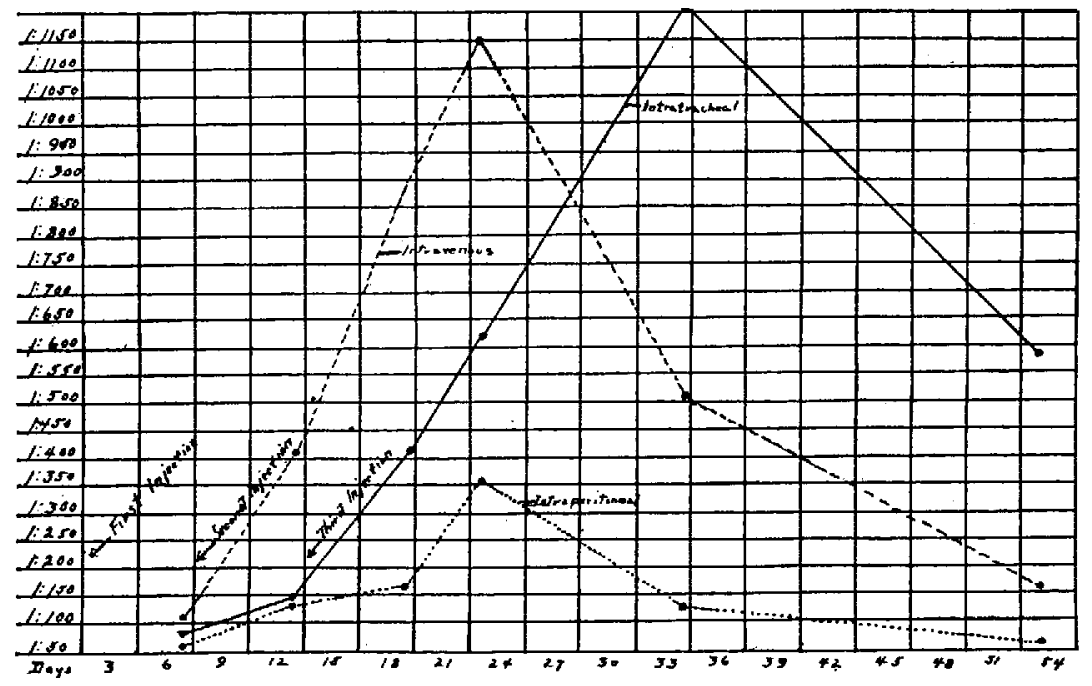

Chart 6.-Production of hemolysin for sheep erythrocytes. 
and 40 days after the last inoculation were $1: 860,1: 1,030,1: 860$ and $1: 560$ as compared to averages of $1: 900,1: 1,100,1: 400,1: 100$ obtained for one animal successfully injected intravenously. With sheep cells, the averages for 3 animals injected in the vein were $1: 830,1: 1,100$, $1: 460$ and $1: 100$ as compared with averages of $1: 360,1: 560,1: 1,160$ and 1:530 for the intratracheally injected animals, 5, 10, 20 and 40 days after final injections. Again it is to be noted that no accidents occurred in the series of animals injected intratracheally with human erythrocytes in contradistinction to the 2 fatalities reported after intravenous injection and the well-known accidents so often attendant on the intracirculatory injection of heterogenous hemic material.

The production of bacteriolysins and bactericidins after intratracheal injections of Bibrio cholerae compares most favorably with the production noted after intravenous injections of these organisms. Most of the animals in the intratracheally inoculated series produced lytic serum far more powerful and possessing bactericidal powers far more marked than did the animals injected intravenously.

The practicability of antibody production by intratracheal injections of some antigens seems established. That such a method may offer decided advantages in the production of antiserum for organisms to which ordinary laboratory animals are highly susceptible seems plausible. Again, in the production of lytic serums, especially for human erythrocytes, the method appears to be especially promising.

\section{CONCLUSIONS}

Antibodies are produced in animals by the intratracheal inoculation of various antigens.

Agglutinins for B. typhosus and B. dysenteriae are as readily produced by this method as by the intravenous method.

Precipitins can be demonstrated in as high titer in animals injected intratracheally with human and horse serums as when such injections are made intravenously.

Lysins for human and sheep erythrocytes are produced by intratracheal injections, but stch production requires a greater length of time before being evidenced than following the intravenous injections of similar quantities of antigens.

Bacteriolysins for Vibrio cholera are elaborated earlier and in larger quantities following intratracheal injections than following intraperitoneal injections. 
No fatal results followed attempts at producing various antibodies by intratracheal methods.

The further study of this apparently safe and efficient method of antibody production is suggested especially with virulent organisms for which the ordinary laboratory animals are highly susceptible as antigens. 